\title{
Operation of Mosul - Dokan Reservoirs and Samarra Barrage Using HEC - ResSim Model During Dry Period
}

\author{
Thabet M. Abdulateef ${ }^{a} *$, Raad H. Irzooki (iD) ${ }^{b}$, Ali S. Abbas ${ }^{c}$ \\ ${ }^{a}$ Civil Engineering Department, University of Technology, Baghdad, Iraq. \\ ${ }^{b, c}$ Environmental Engineering Department, Tikrit University, Saladin, Tikrit, Iraq. \\ *Corresponding author Email: 40157@uotechnology.edu.iq
}

\section{H I G H L I G H T S}

- A new stepped spillway shape was used in
experimental work under the skimming flow
regime by adding block (tooth) on the step.
- The tooth-stepped spillway reduces the
positive and negative pressure on steps close
to the crest by a large amount and especially
at high discharge.
- When the spacing between tooth increase
the pressure along the chute will have bad
distribution compare to the traditional
model.

\section{A R T I C L E I N F O}

Handling editor: Wasan I. Khalil

\section{Keywords:}

Simulation

Alternative

Operation

Release

\begin{abstract}
A B S T R A C T
The issue of time series records containing low inflow than normal, such critical period results in shortage in reservoir storage, thereby reduction in the reservoir's releases that satisfy the demands. When the expected available water is less than the demand, releases may be curtailed, and the reservoir is under stress. This study presents an application of HEC - ResSim model to simulate the operation of Mosul, Dokan Reservoirs, and Samarra Barrage during the dry period 1999-2000 (modeling of historical data). Simulated results and recorded data were compared in order to, first improve the applicability of the software to simulate reservoir operation by calibrating the model during the period (1990 2000), and the second to identify the similarity and differences between recorded and model result during dry period. The aim of applying this software is to manage the operation of reservoir's system by establishing an operation policy for each reservoir. The simulation plots for Mosul Reservoir, exhibit storage pool elevation within the conservation zone including the ability of release of minimum downstream requirement and the operating Dokan pool reservoir is less than the conservation level. The upstream of Samarra Barrage pool elevation is affected by the look back level with the consideration of normal and minimum operation levels.
\end{abstract}

\section{Introduction}

Water resources is an area of study rich in problems and challenges. Reservoir operation is one of these challenging problems and it is operated according to a set of rules to store and release water depending on the purpose it is required to serve. Further, the mathematical form used to model the reservoir shows up in numerous industrial and commercial settings where the management of inventory is at issue. Reservoirs could have different operation functions. These functions include water supply for municipal and industrial use, irrigation, flood control, hydropower, and flow maintenance for navigation or aquatic life. The simplest of the reservoir operation policies is the standard linear operation policy in which release values are a function of water availability. Climate change, limited water resources, and population growth, result in unbalance between the release of water and the demand. In such circumstance it is customary to maintain safe operation during these critical conditions. The trend of most research is moving toward increasing storage, and management of water resources during successive dry periods. Recently the HEC-ResSim software developed by US Army Corps of Engineers has the property to operate the reservoir according to the rule curve [1]. That is specifying the release values to simulate the operation according to reservoir rule curve [2]. HEC-ResSim consist of three major modules, the first one is the watershed module which involves establishing streams line alignment, reservoir position, lakes, country border, projected with the aid of ArcGIS layers and assign the computation points. The second module is reservoir network module, the configuration of the watershed is accomplished by adding stream reaches, junctions, definition of the network by editing all reservoirs and reaches with the physical characteristics (time serious data involving stream flows, historical reservoir inflow and outflow) with reservoir pool elevations, and operational data representing applied release function within the operation zone. The result of creating the 
model is achieved by running the operational alternatives through a time window of simulation which is known as simulation module [3]. Jebbo, and Awchi studied the effect of Aljazeera irrigation requirement on hydropower generation in Mosul Dam by building HEC-ResSim model with two alternatives, one for maximizing the hydropower, and the second is to minimize the deficit in the requirement of Aljazeera's project [4].Khayoon,et al., used historical data for twenty years to simulate the operation of Mosul Reservoir[5]. AL-Yaseen, et al., used the feature of HEC-DSS to develop daily data from three times monthly reported data [6].Eliza I.Tica, et al. applied HEC-ResSim model in order to optimize the generation of hydropower for Vidraru Reservoir. The simulation model was formulated under deterministic condition with known input data, monthly mean flow with the corresponding energy demand, [7]. The main objective of this study is to develop HEC-ResSim model to simulate and evaluate the operation of Mosul, Dokan, and Samarra pool reservoirs system during dry period and present the merits of HEC-ResSim to specify the releases from pool reservoirs according to the operation function with the corresponding storage during time of operation.

\section{Materials and methods}

\subsection{Study area}

The study area consists of Mosul, Dokan Reservoirs and Samarra Barrage which are located on the Tigris River in Iraq. Brief descriptions of the reservoirs are presented in the following items:

1) Mosul Dam is one of the biggest dams in northern part of Iraq, located at the coordinates of $36^{\circ} 37^{\prime} 49^{\prime \prime} \mathrm{N}$ and $42^{\circ} 49^{\prime} 23^{\prime \prime}$ E. It is an earth embankment dam, with height of $113 \mathrm{~m}$, and 3,650 m length. Mosul Dam is type of multi purposes reservoir comprising of irrigation, flood control, and hydropower generation. The flow is diverted into turbines by four penstocks leading to the power station [8].

2) Dokan Dam is one of the oldest arched concrete dams in Iraq, which was constructed on the lesser Zab River about $67 \mathrm{~km}$ north - west of Sulaymaniyah city. The coordinate of this dam location is $35^{\circ} 57^{\prime} 15^{\prime \prime} \mathrm{N}$ and $44^{\circ} 57^{\prime} 10^{\prime \prime}$ E close to Ranya city. The dam height is $116.5 \mathrm{~m}$ and $360 \mathrm{~m}$ in length with crest elevation at $516 \mathrm{~m}$. Its serves for storage excess water, irrigation, and power generation [9].

3) Samarra Barrage is located on the Tigris River, north of Baghdad city close to Samarra city, with coordinate of $34011^{\prime} 27^{\prime \prime} \mathrm{N}$ and 430 51' 19" E. The main objective of the barrage is controlling the flood by diverting excess water to Tharthar Lake which is located to west of Tigris River with coordinates $34016^{\prime} 29^{\prime \prime} \mathrm{N}$ and $43018^{\prime} 28^{\prime \prime} \mathrm{E}$ with covered area $2000 \mathrm{~km} 2$. It collects flood water received from Samarra Barrage conveyed by artificial canal [10]. The reservoirs positions are illustrated in Figure (1).

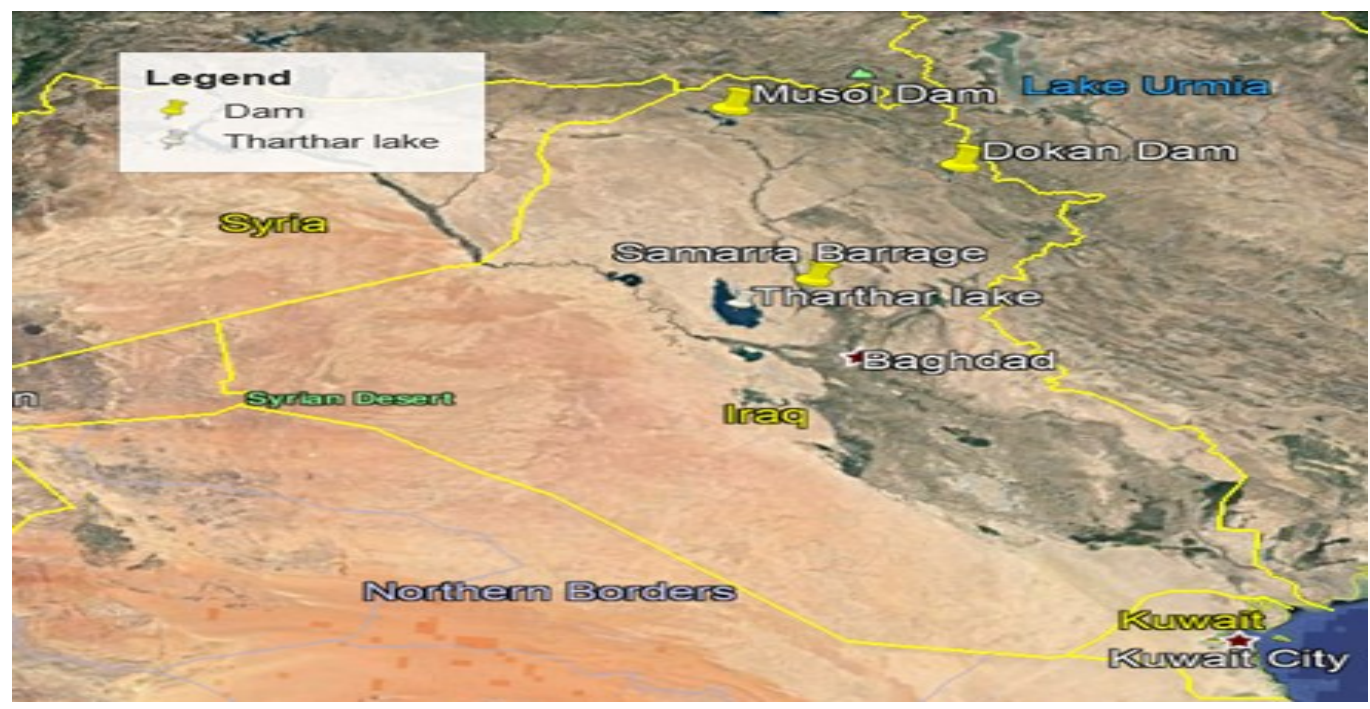

Figure 1: Lay out of reservoirs (from google earth)

\subsection{Model configuration}

The creation of HEC-ResSim software, consists of consecutive modules, these modules established the performance of the model by plotting reservoir simulation. Figure (2) illustrate model construction. The modules implementations are as follow: 


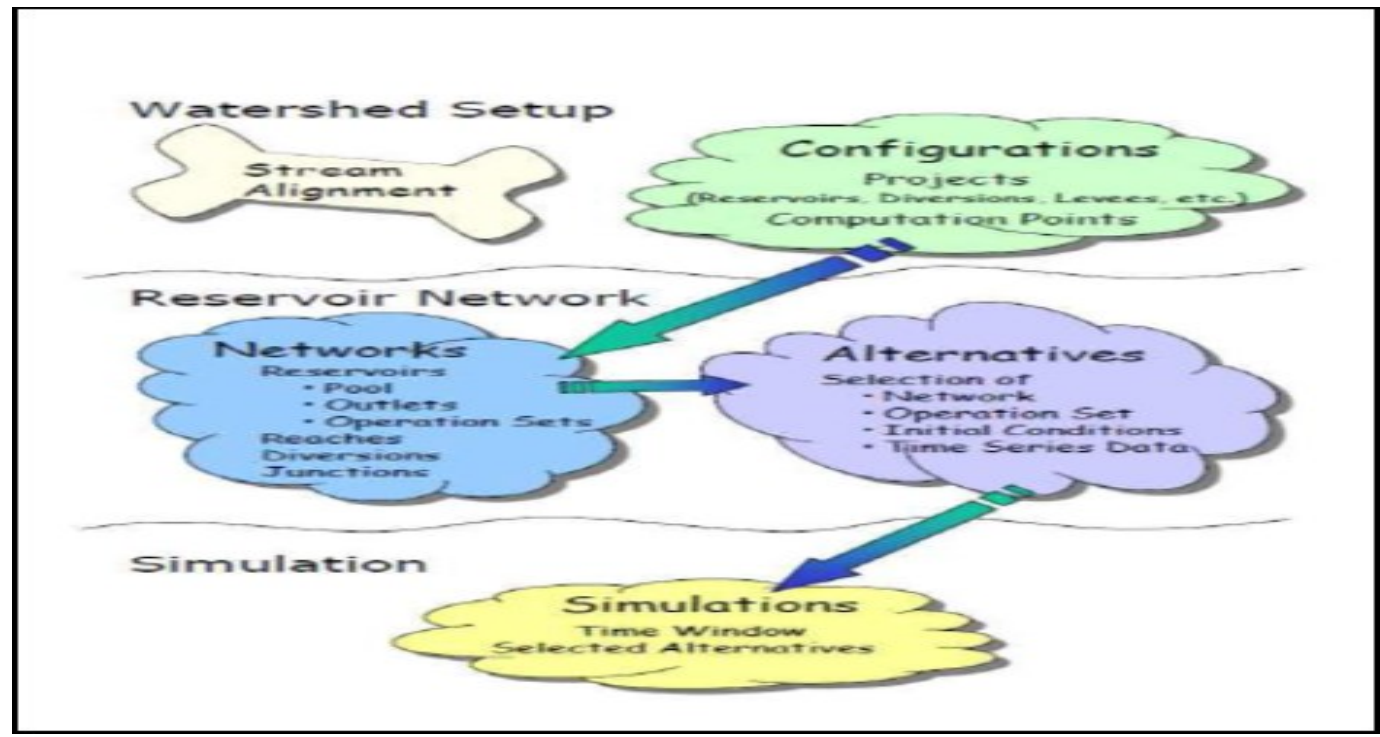

Figure 2: Steps of model simulation [1]

a) Watershed module: The first step in model development is watershed module in which the stream alignment was formed by imported rivers, streams, lakes, reservoirs, and country border from arc - shape file. Figure (3) illustrate the configuration of the watershed that has been done with this module.

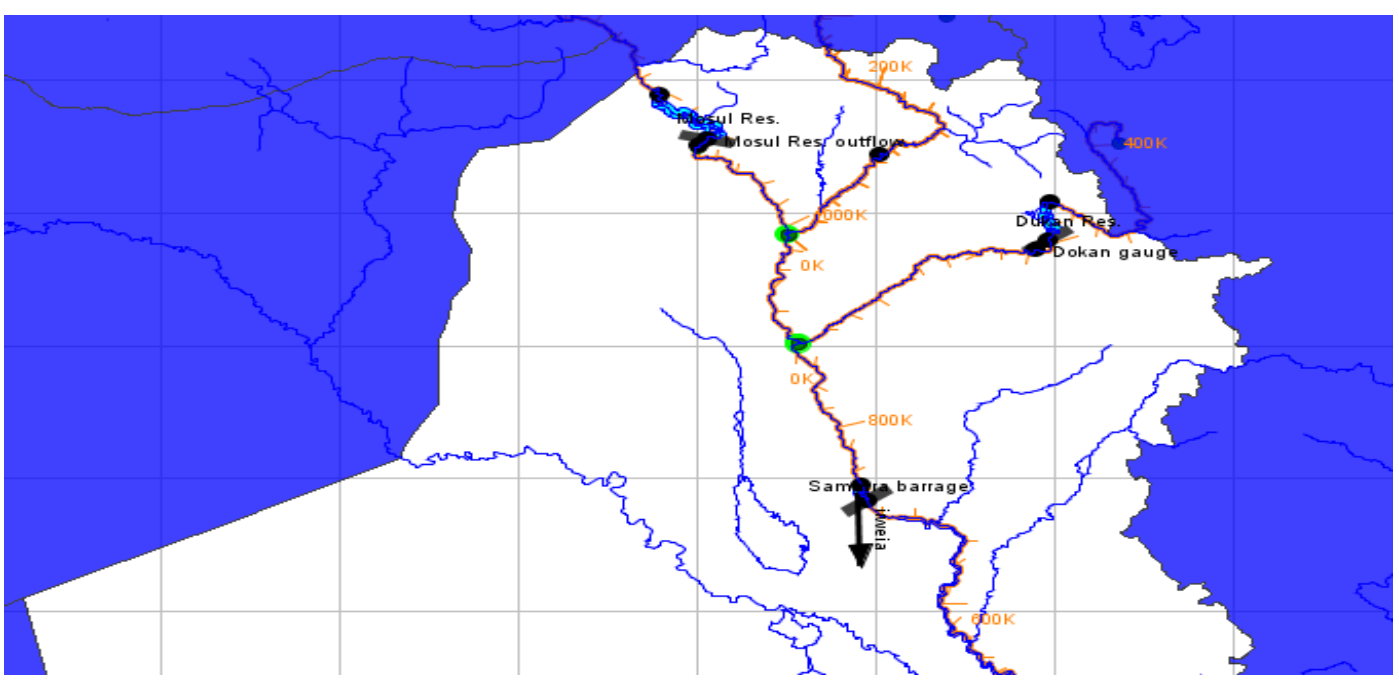

Figure 3: Watershed set up module

b) Reservoir network module: This module is considered a major part of model development. A scheme of reservoirs' network was given in Figure (4). This module includes physical properties and operating rules. The physical properties for reservoir are related with storage area, elevation relationships, rule curve levels, evaporation rates. Another type of data is relating with editing reaches, specifying $\mathrm{X}$ and $\mathrm{K}$ values, (Muskingum coefficients) required for routing reach between two junction points. The operating rule means, assigning operation set for each reservoir, specify operation zone, and identify an operation rule (if statement was used in this study) [11]. The operations policy for the pool reservoirs are the following:

First for Mosul Reservoir, the inflow is limited to more than or equal to $200 \mathrm{~m}^{3} / \mathrm{s}$, with minimum release of $200 \mathrm{~m}^{3} / \mathrm{s}$ function of date. For Dokan reservoir, if the pool reservoir inflow is greater than or equal to $75 \mathrm{~m}^{3} / \mathrm{s}$, then $60 \mathrm{~m}^{3} / \mathrm{s}$ is the maximum limit of release function of date.

The condition for Samarra Barrage considers reservoir pool inflow is less than or equal to $800 \mathrm{~m}^{3} / \mathrm{s}$ then, $400 \mathrm{~m}^{3} / \mathrm{s}$ is applied as a release of minimum limit type function of date.

Figures (5), (6), and (7), (8) illustrate the operation rules for Mosul and Dokan, respectively. For Samarra Barrage, the operating rules are giving in figures (9) and (10) respectively. 


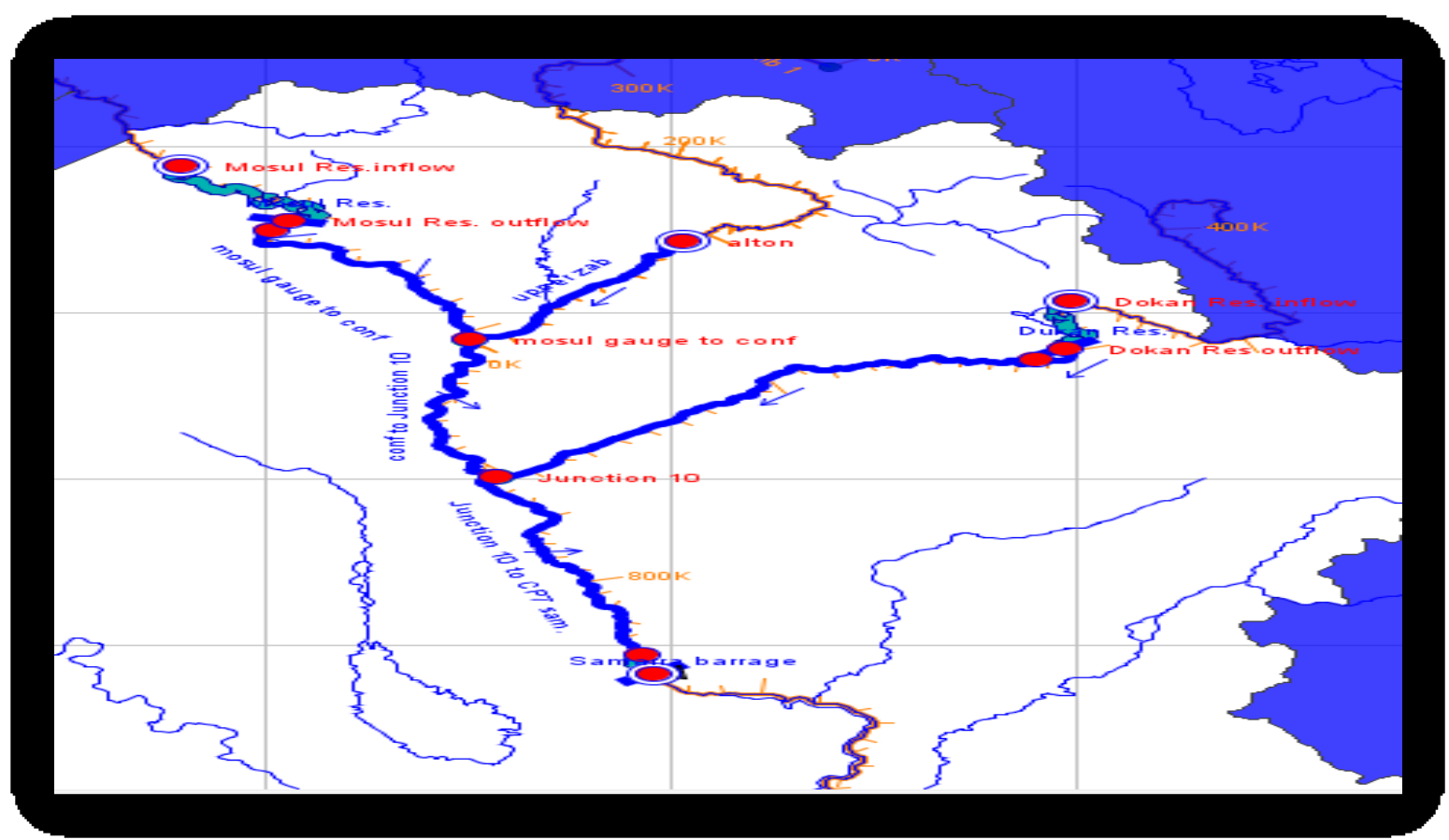

Figure 4: Schematic of reservoirs module

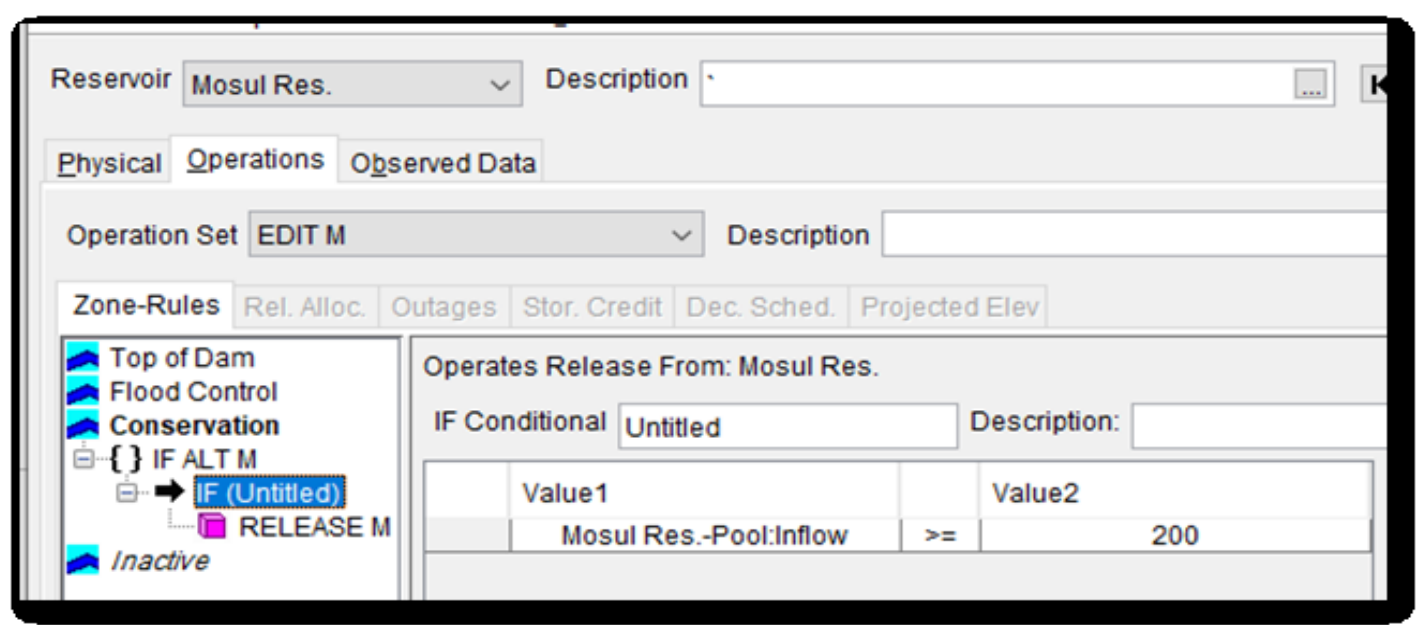

Figure 5: Conditional release for Mosul

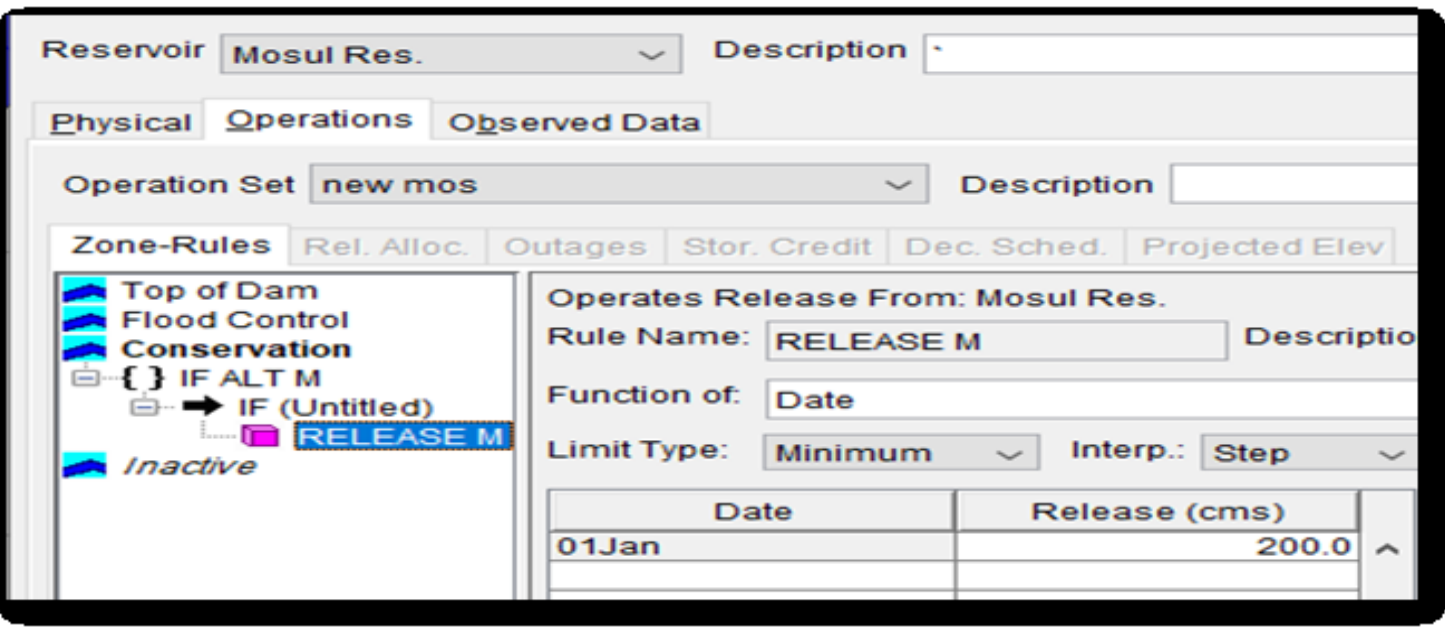

Figure 6: Functional release for Mosul 


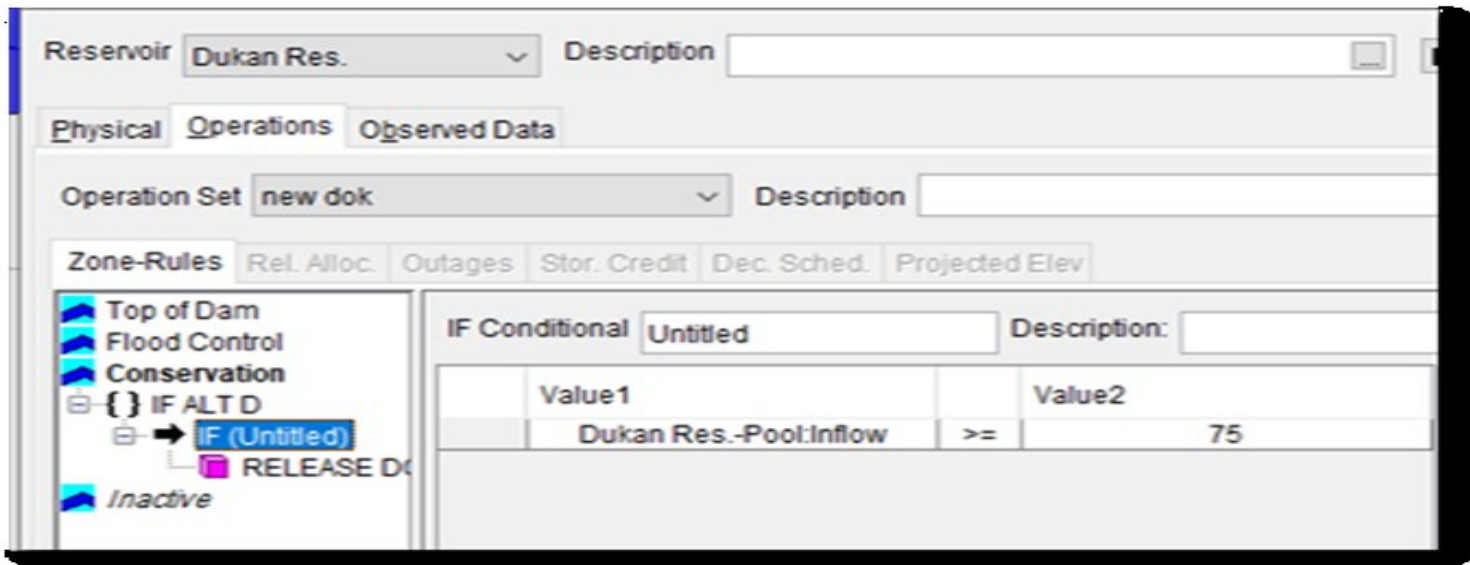

Figure 7: Conditional release for Dokan

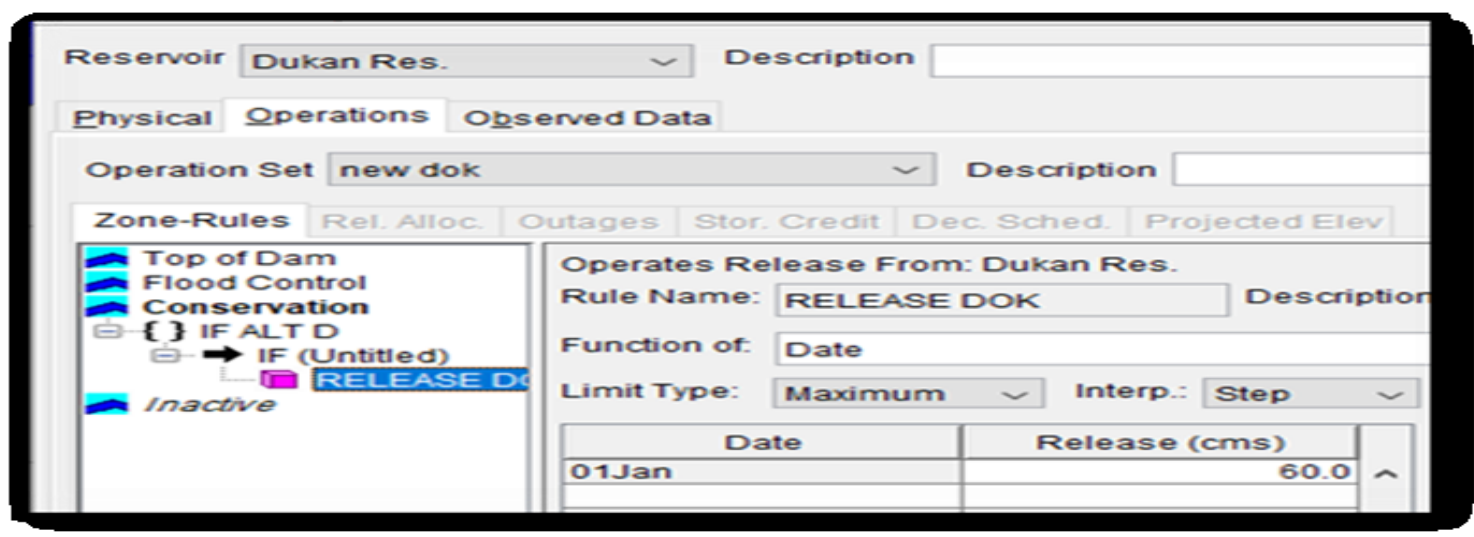

Figure 8: Functional release for Dokan

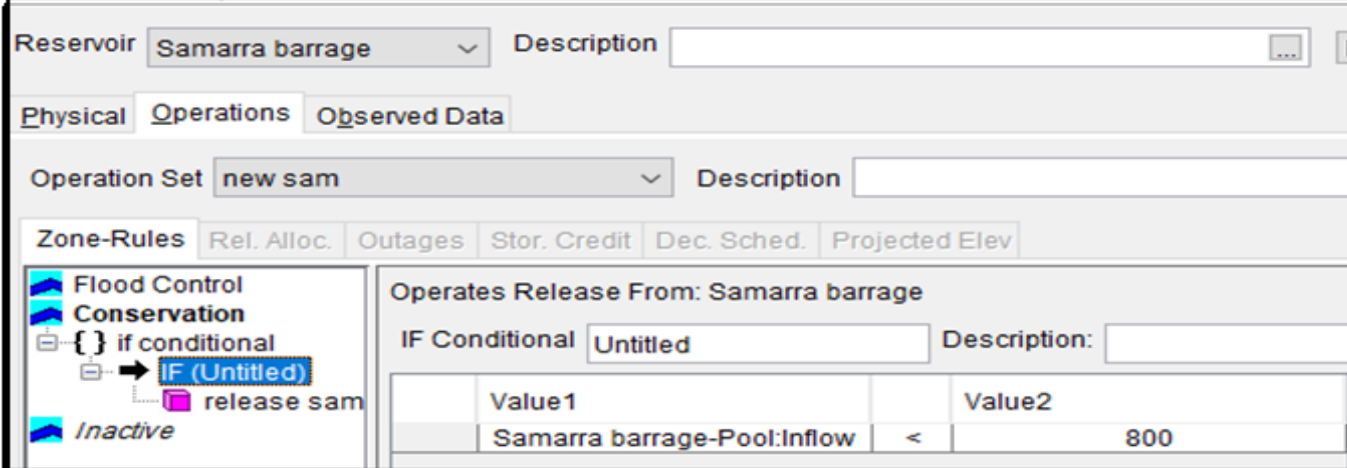

Figure 9: Conditional release for Samarra Barrage (Dry period)

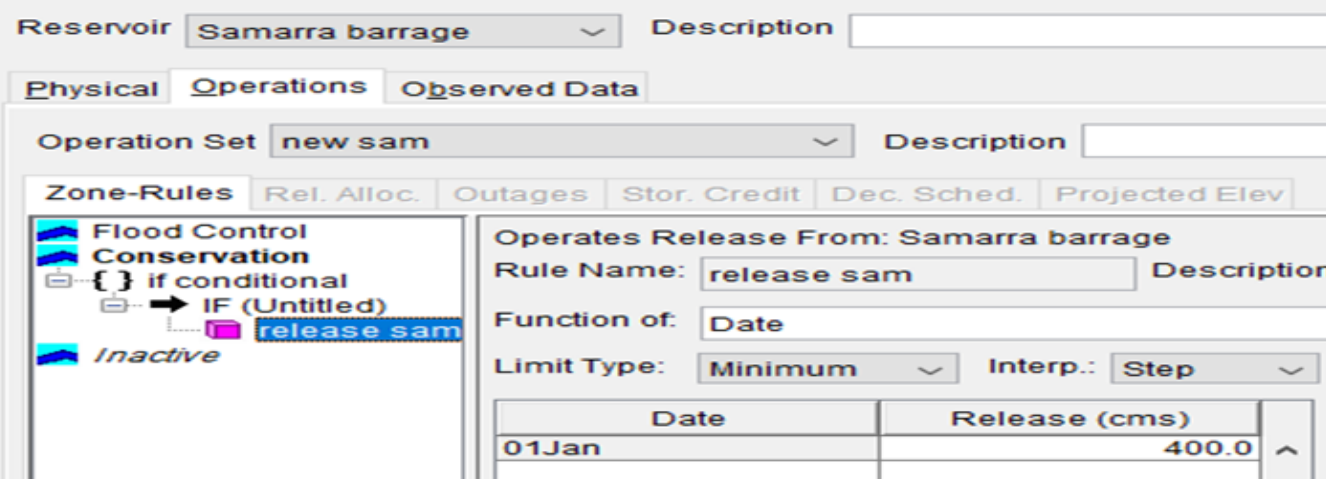

Figure 10: Release function for Samarra Barrage (Dry period) 
c) Simulation module: In HEC- ResSim, the process of operating alternative involves creating an operation set specified for each reservoir in the network, select an operating function, and from alternative editor menu, insert look back period with time series of inflow data, all these rules should be done with reservoir network module [12]. Simulation results are accomplished by assigning three simulation times period denoted as starting simulation date, look back period date, and end date of simulation time in the simulation time window.

\section{Model calibration}

The target of calibration model are the observed and computed flows through the period between 1990 and 2000 , with the verification of the calibrated model for Mosul Reservoir by calculating $\mathrm{R}^{2}$, coefficient of determination between reported and calculated data and the second parameter is Nash - Sutcliffe as shown in Figure (11).

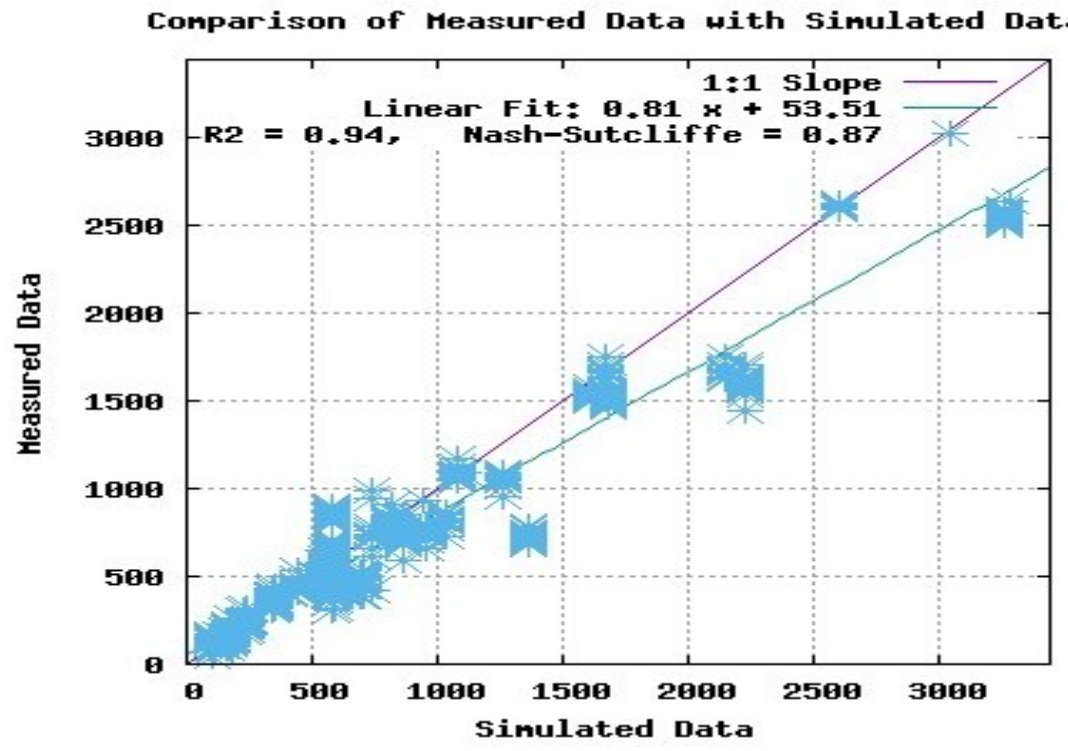

Figure 11: Objective assessment with statistical parameters

\section{Results of simulation module}

\subsection{Simulation plots}

The results of Simulation module during operating time are presented by Figure (12), Figure (13) for Mosul, and Dokan Reservoirs respectively, and Figures (14) and (15) for Samarra Barrage considering two levels of look back periods (68m) and $(67.5 \mathrm{~m})$ respectively.

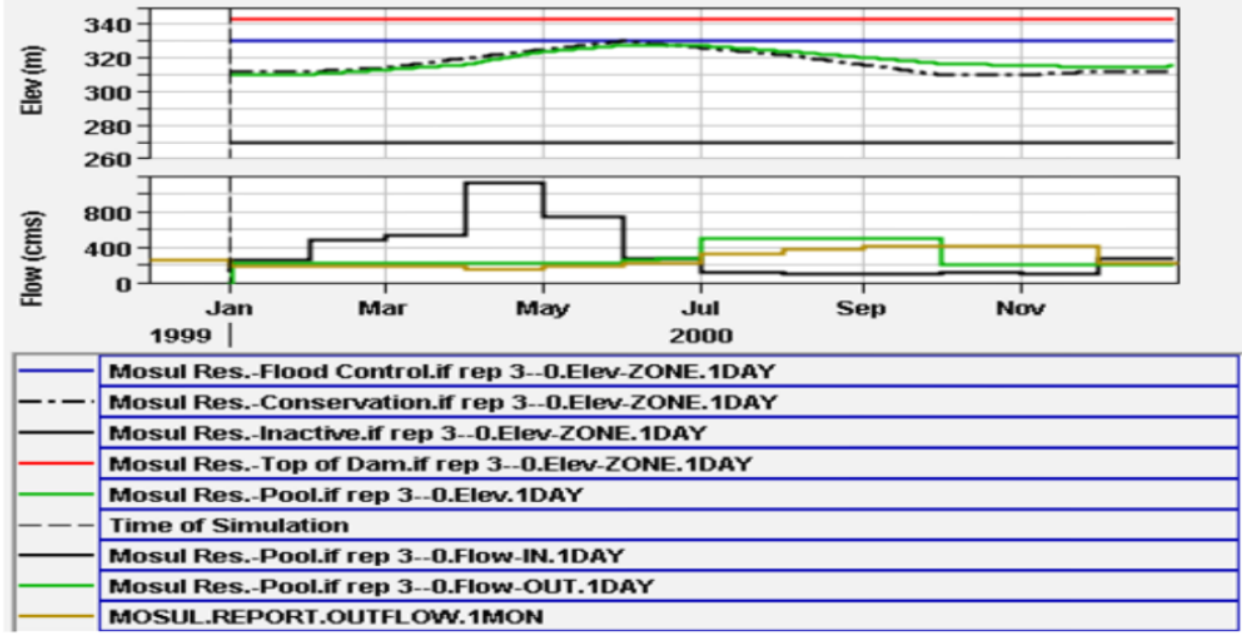

Figure 12: Mosul time varying release 


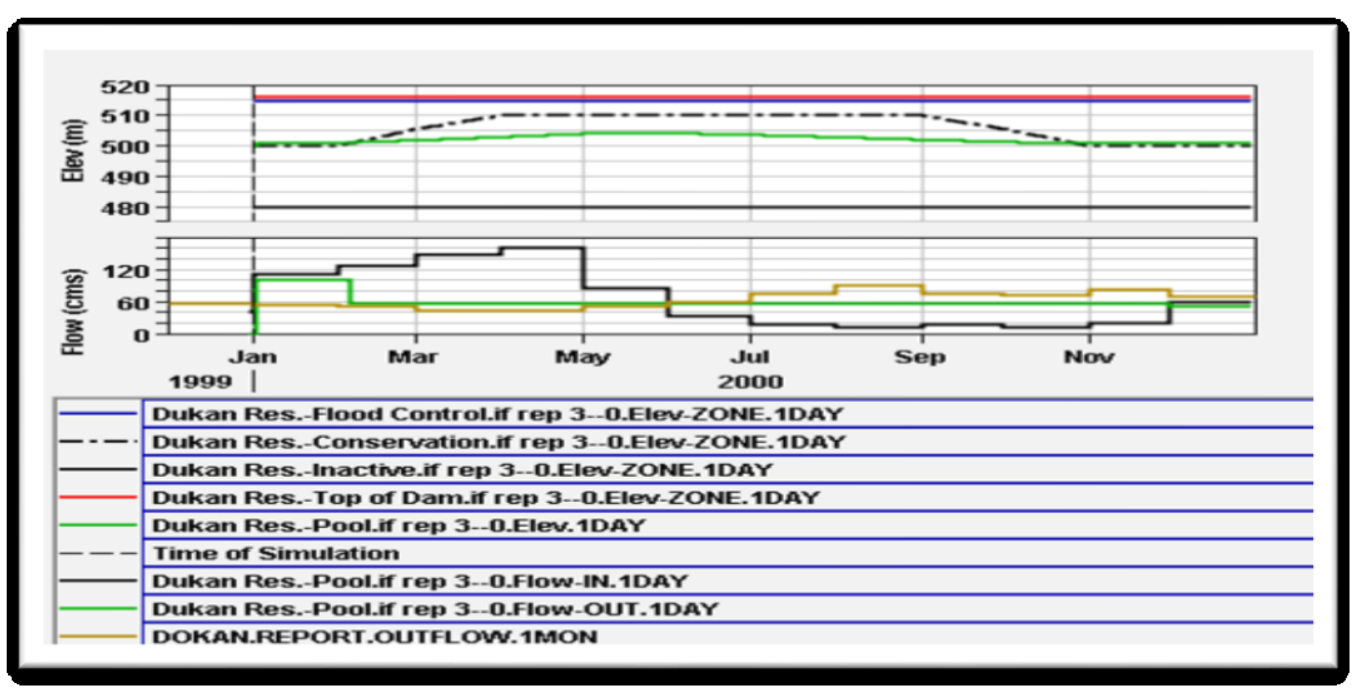

Figure 13: Dokan time varying release

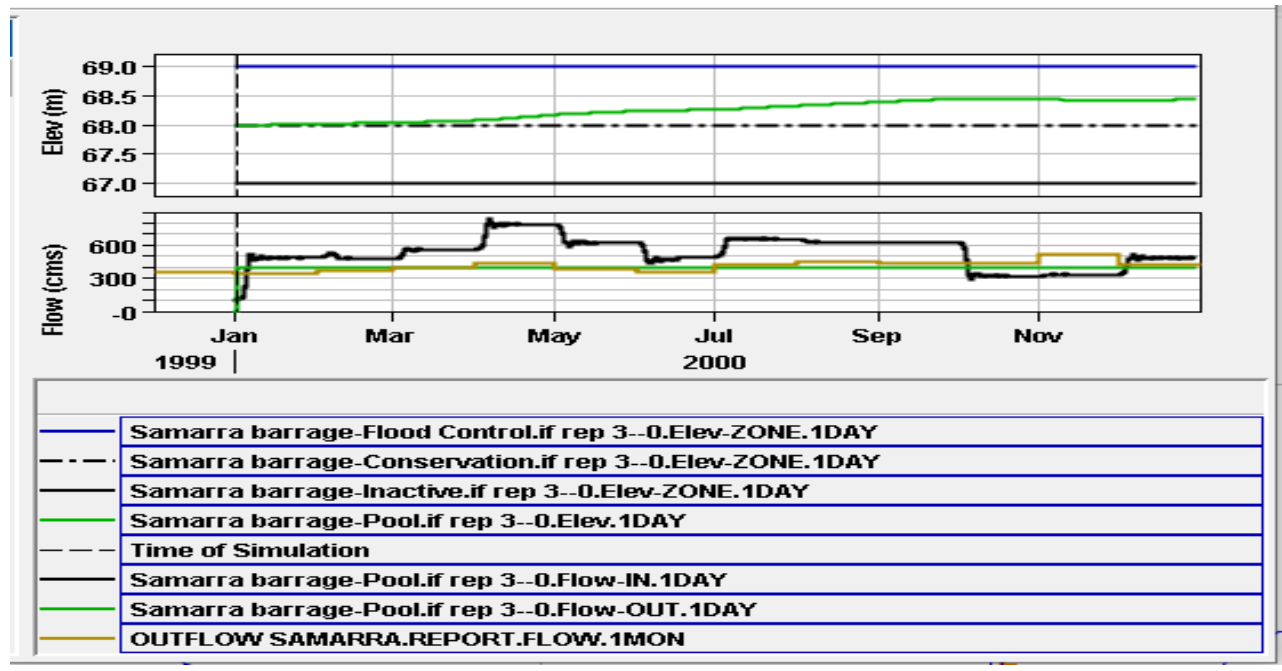

Figure 13: Samarra time varying release $68 \mathrm{~m}$

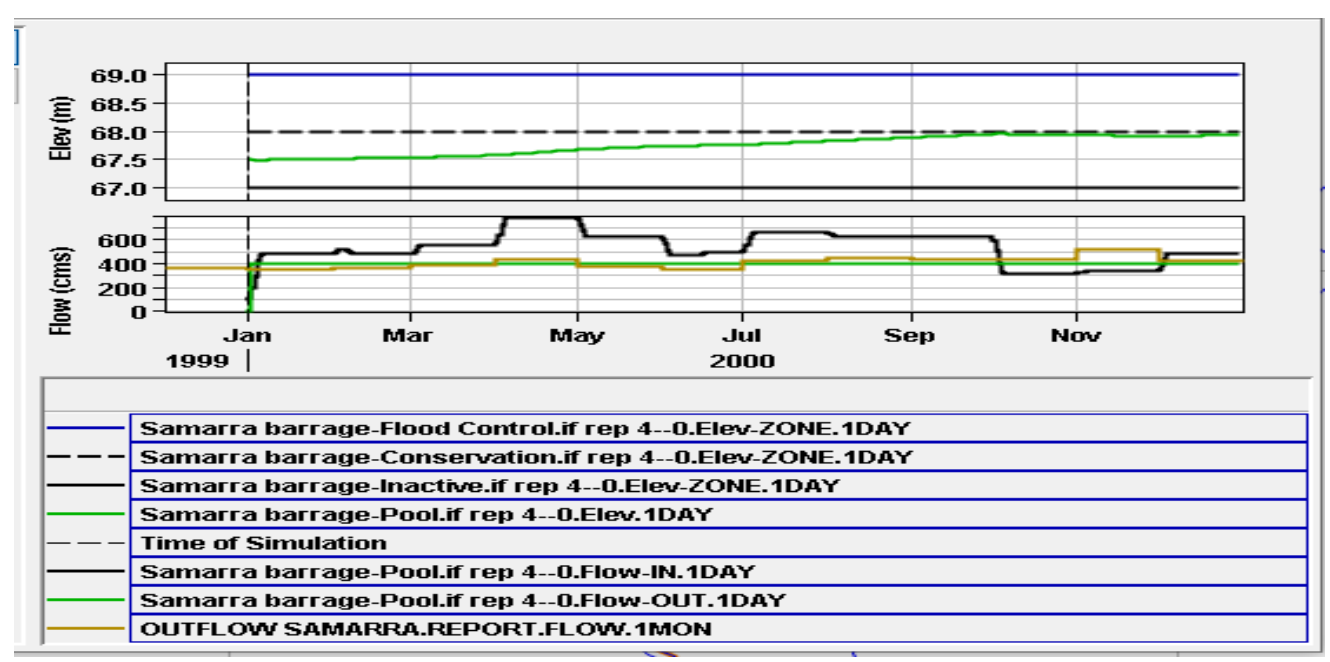

Figure 14: Samarra time varying release $67.5 \mathrm{~m}$

\subsection{Result analysis}

The results obtained by applying IF-BLOCK function, as an operational rule. The minimum release of $200 \mathrm{~m}^{3} / \mathrm{s}$ was specified for Mosul Reservoir, and $60 \mathrm{~m}^{3} / \mathrm{s}$ for Dokan Reservoir type of minimum limit. The operational levels are with look back elevation of $310 \mathrm{~m}$ for Mosul Reservoir and 500m for Dokan Reservoir. Figures (12), and (13), illustrate the plots of reservoirs operation. The upper graph region shows, the operating zones, computed elevation of the reservoir pool, and the 
observed pool elevation. The lower graph illustrates reported and computed outflow, and time - series inflow data. Figures (12) illustrate matching between computed and the conservation pool elevation for Mosul Reservoir. This matching is strongly related to the release values from Mosul Reservoir. The conditional release statement applied as an operation rule for Mosul and Dokan Reservoirs specify $200 \mathrm{~m}^{3} / \mathrm{s}$ as minimum release with $560\left(\mathrm{~m}^{3} / \mathrm{s}\right)$ as maximum release. The simulation plot for Dokan Reservoir yields $60 \mathrm{~m}^{3} / \mathrm{s}$ as minimum release with $100 \mathrm{~m}^{3} / \mathrm{s}$ as upper release limit causing drop in reservoir pool elevation.

For Samarra Barrage, with it is location at downstream Mosul and Dokan Reservoirs must handle the inflow and make a proper allocation to meet downstream water supply requirements in dry condition. Two alternatives are considered for Samarra Barrage, the first one assigned look back pool elevation equal to conservation level (68m) which represent the normal operation as shown in Figures (14) yields rising in pool elevation reaching $(68.5 \mathrm{~m})$ at the end of operation time and the second alternative established the look back period below the conservation level $(67.5 \mathrm{~m})$ as shown in Figure (15). The simulation plot yields rising in the pool elevation, and established the normal operation level at the end of simulation period.

\section{Conclusions}

1) The model provide the ability to simulate the operation of Mosul, Dokan, and Samarra barrage reservoirs, by using IF - BLOCK function as an operational rule.

2) From simulation plots, the operation rule curves are with the upper limit of the conservation zone For Mosul reservoir since the HEC-ResSim seek to achieve the conservation storage level during operation period, causes suitable releases yields operating reservoir curve close to the design rule curve.

3) For Dokan Reservoir, the simulation result in differences between simulated pool reservoir and the design rule curve (observed) causes deficit in reservoir storage due to limited of reservoir inflow. As reservoir storage is computed at the end of each period time of simulation that is equal to the previous storage plus inflow minus all losses, and because of the critical inflow records result in decrease reservoir storage and thereby drop in pool elevation.

4) Samarra Barrage must handle the inflow from upstream and makes a proper allocation to meet downstream water requirements in dry conditions. The specified release $\left(400 \mathrm{~m}^{3} / \mathrm{s}\right)$ is very close to the reported values and enhanced the reservoir pool elevation.

\section{References}

[1] J. D. Klipsch and T. A. Evans, "Reservoir operations modeling with HEC-Res.Sim", In Proceedings of the 3rd Federal Interagency Hydrologic Modeling Conference, Reno, NV, USA, 3 Apr. 2006, [Online], Available: https://acwi.gov/hydrology/mtsconfwkshops/conf proceedings/3rdFIHMC/7E Klipsch.pdf .

[2] M. Wanielista, R. Kersten, and R. Eaglin, "Hydrology: water quantity and quality control" $2^{\text {nd }}$ edition, by john wily \& sons, Inc. London, copyright (C) 1997.

[3] U.S. Army Corps of Engineers, HEC-ResSim Reservoir System Simulation - User's Manual, version 3.1, Institute for Water Resources, Davis, CA, Computer Programming Report, CPR - 82, May, 2013.

[4] B.Jebbo, T.A. Awchi, "Simulation of Mosul Dam Reservoir operation for and Hydropower generation", Engineering and Technology Journal, Vol. 37, No. 1, pp.64 - 69, 2019.

[5] S. K. Thair, S. M. Ayad, and H. M. Hasan, "Reservoir Operation by Artificial Neural Network Model (Mosul Dam-Iraq, as a Case Study)", Engineering and Technology Journal, Vol.33, No.7, PP.1697- 1714, 2015.

[6] F.H.AL- Yaseen, and M.M.AL-Mukhtar,"Modelling the Ecosystem Behavior of Abu- Ziriq Marsh in South of Iraq under Different Water Discharges Scenarios" Engineering and Technology Journal, vol. 37, No. 10, pp.442 - 452, 2019.

[7] M. Meshkat, and J. D. Klipsch, "Modeling of Interconnecting Reservoirs with HEC - ResSim", World Environmental and Water Resources Congress, Minneapolis, Minnesota, June 2018.

[8] E.Tica, K. A.Rashid, O.V. Sima, Denisa M. P ,Andreea- Roxana Coman and Bogdan Popa," HEC-ResSim Optimization Model on Vidraru Hydropower Development", Journal of Engineering Science and Technology Review, Vol. 37, No.3,pp. $191-195,2020$.

[9] L. S. Aziz, and Hekmat M. I., "Simulation - Optimization model for Dokan reservoir System Operation", Suliamani Journal for Engineering Science, Vol.4, No.5, pp. 7 - 25, 2017.

[10] V. K. Sissakian,"Genes and Age Estimation of the Tharthar Depression, Central West Iraq", Iraqi Bulletin of Geology and Mining, Vol.7, No.3, pp. $47-62,2011$.

[11] P.G. Lara, J.D. Lopes, G.M Luz, and N.B. Bonuma, "Reservoir operation employing HEC-ResSim: case study of Tucuruí dam, Brazil", 6th International Conference on flood management, Sao Paulo, Brazil, 2014.

[12] U.S. Army Corps of Engineers, "Delaware River Basin Flood Analysis Model", Delaware River Basin Comp. West Trenton, public Rep. PR -73, February 2010. 